\title{
Arbejde - sundhed og sygdom
}

Tidsskrift for Forskning i Sygdom og Samfund

Nr. 16, 2012 


\title{
Tidsskrift for Forskning i Sygdom og Samfund
}

\author{
Nr. 16: Arbejde - sundhed og sygdom
}

\section{(C) 2012 forfatterne og udgiverne.}

Redaktion:

Mette Bech Risør (ansv.), Forskningsenheden for Almen Praksis, Universitetet i Tromsø

Torsten Risør, Allmennmedisin, Institutt for Samfunnsmedisin, Universitetet i Tromsø Gitte Wind, Afdeling for Antropologi og Etnografi, Aarhus Universitet

Ann Dorrit Guassora, Forskningsenheden for Almen Praksis, Københavns Universitet Susanne Rewentlow, Forskningsenheden for Almen Praksis, Københavns Universitet Rikke Sand Andersen, Forskningsenheden for Almen Praksis, Aarhus Universitet Claus Bossen, Institut for Medie- og Informationsvidenskab, Aarhus Universitet

\section{Gæsteredaktør:}

Claus Vinther Nielsen, Marselisborgcenteret, Region Midt \& Klinisk Socialmedicin, Institut for Folkesundhed, Aarhus Universitet

Peer review: Foretages af et tværvidenskabeligt panel bestående af bl.a. læger, antropologer, filosoffer, historikere, psykologer, politologer og sociologer.

Proof: Thomas Christian Mikkelsen

Layout og prepress: Thomas Christian Mikkelsen \& Ea Rasmussen

Tryk: Werk Offset, Højbjerg.

Udgiver:

Foreningen Medicinsk Antropologisk Forum,

Afd. for Antropologi og Etnografi, Aarhus Universitet, Moesgård, 8270 Højbjerg.

Bestilling, abonnement, henvendelser og hjemmeside:

Tidsskrift for Forskning i Sygdom og Samfund.

Afd. for Antropologi og Etnografi, Aarhus Universitet, Moesgård, 8270 Højbjerg

Torsdag kl. 9-12, tlf. 87162063,

Email: sygdomogsamfund@hum.au.dk

Hjemmeside og artikler:

ojs.statsbiblioteket.dk/index.php/sygdomogsamfund/index

ISSN (tryk): 1604-3405

ISSN (online): 1904-7975

Tidsskriftet er udgivet med støtte fra Forskningsrådet for Kultur og Kommunikation.

Formål:

Tidsskrift for Forskning i Sygdom og Samfund er et tværfagligt tidsskrift, der tager udgangspunkt i medicinsk antropologi. Tidsskriftet har til formål at fremme og udvikle den forskning, der ligger i grænsefeltet mellem sundhedsvidenskab og humaniora/samfundsvidenskab. Tidsskriftets målsætning er at fungere som et forum, hvor disse fag kan mødes og inspirere hinanden - epistemologisk, metodisk og teoretisk - i forskellige forskningssammenhænge. Tidsskriftet formidler den debat og teoretiske udvikling, der foregår i de voksende faglige samarbejds- og forskningsinitiativer, der udspringer af dette grænsefelt. Tidsskriftet henvender sig til alle med interesse for forskning i sygdom og samfund og i særlig grad til sundhedsmedarbejdere i forsknings- og undervisningssammenhæng med forbindelse til tværfaglige miljøer.

Aims and scopes

The Journal for Research in Sickness and Society is an interdisciplinary journal which has a theoretical background in medical anthropology. The aim and purpose of the journal is to promote and develop research in the borderland between the health sciences and the humanities/the social sciences. The goal of the journal is to function as a forum in which these disciplines may meet and inspire each other epistemologically, methodologically and theoretically. The journal conveys the debate and theoretical development which takes place in the growing collaboration and research initiatives emerging from this borderland. The journal addresses all with an interest in research in sickness and society and especially health professionals working with education and/or research in interdisciplinary institutions. 


\section{Indhold}

Claus Vinther Nielsen, Gitte Wind \& Mette Bech Risør

Introduktion 5

Anne Møller \& Susanne Reventlow

Muskuloskeletal aldring, arbejdsevne og 'sundhedsbrøken' 15

Einar Baldvin Baldursson

Social smerte i det moderne arbejdsliv ud fra et arbejdspsykologisk

perspektiv 33

Steen Brock \& Bo Allesøe Christensen

Normative og metodiske vinkler på 'arbejde' som et sundhedsøkonomisk begreb 63

Eva Ladekjær Larsen, Pernille Tanggaard Andersen \& Carsten Kronborg Bak

Fortællinger om et liv som arbejdsløs og socialt ekskluderet 83

Torunn S. Olsen \& Nils Fleten

Må sykefravær legitimeres med legemelding? 105

Tina Bømler

Socialarbejdere i et spændingsfelt mellem politik og brugernes behov 127

Claus D. Hansen

Fra sygdomsforfald til sygefravær - arbejde og sygdom mellem rettigheder og pligter i den moderne velfærdsstat 149

Abstracts in English 173

Forfatterliste 179

Skrivevejledning 183

Beskrivelse af nr. 17186 


\section{Socialarbejdere $\mathrm{i}$ et spændingsfelt mellem politik og brugernes behov}

\section{Tina Bømler}

Institut for Sociologi og Socialt Arbejde, Aalborg Universitet boemler@socsci.aau.dk

Bømler, T. (2012). Socialarbejdere i et spændingsfelt mellem politik og brugernes behov. Tidsskrift for Forskning i Sygdom og Samfund, nr. 16, 127-147.

Artiklen tager udgangspunkt $i$ aktivering af sygedagpengemodtagere, der har været et lovpligtigt krav siden 1. januar 2010. Aktiveringskravet på sygedagpengeområdet er et udtryk for en holdningsændring til, hvordan vi bliver raske. Med ændringen af sygedagpengeloven bliver det slået fast, at det der kan sikre en hurtigere tilbagevenden til arbejdsmarkedet, er aktivering. Formålet med artiklen er at beskrive og indkredse, hvordan rådgivere og projektmedarbejdere i Aalborg kommune, der arbejder med aktivering af sygedagpengemodtagere håndterer de faglige og etiske dilemmaer, som de oplever som en konsekvens af aktiveringspligten på sygedagpengeområdet. Problemstillingen er begrundet $i$, at vi mangler konkret viden om, hvordan jobcentrene håndterer aktiveringen af sygedagpengemodtagere. Artiklen bygger på et begrænset empirisk materiale, idet der er tale om et pilotprojekt. Pilotprojektet skal ses som en forundersøgelse til en større kvalitativ undersøgelse om de metodiske udfordringer på sygedagpengeområdet. Artiklen er baseret på et fokusgruppe interview med tre rådgivere og to projektmedarbejdere på et jobcenter i Aalborg kommune. De fem jobcentermedarbejdere er alle uddannet socialrådgivere. Pilotprojektets resultater har været overraskende. Selvom de faglige og etiske dilemmaer er til stede, så fylder de mindre end de New Public Management-orienterede omstillinger, der har stået på $i$ snart 30 år. Det er regelstyring, økonomistyring og standardisering af det sociale arbejdes metoder, som 
rådgivere og projektmedarbejdere oplever som den storste barriere i forhold til at udføre fagligt kvalificeret socialt arbejde. Kravene om bl.a. regelstyring, standardiserede metoder og økonomistyring har $i$ høj grad placeret de professionelle socialarbejdere $i$ et spændingsfelt mellem politik og brugere. Det betyder, at de professionelle socialarbejdere konstant skal kunne agere i en organisatorisk kontekst med modsatrettede krav $i$ deres praksis.

Artiklen tager udgangspunkt $\mathrm{i}$ aktivering af sygedagpengemodtagere $\mathrm{i}$ et jobcenter i Aalborg kommune. Formålet med artiklen er at indkredse og beskrive de socialfaglige udfordringer og dilemmaer, som rådgivere og projektmedarbejder oplever i arbejdet med at aktivere sygemeldte borgere. Jobcentret i Aalborg var et af de 16 jobcentre, der deltog $\mathrm{i}$ arbejdsmarkedsstyrelsens forsøgsprojekt forud for lovændringen i sygedagpengeloven og aktiveringskravet af de sygemeldte borgere. Formålet for forsøgsprojektet blev beskrevet således:

"- At bidrage til at kommunerne kan få et godt udgangspunkt for at benytte aktive tilbud til at hjælpe den bredere gruppe af sygemeldte og fleksjobvisiterede hurtigst muligt i job. -At afprøve hvordan anvendelse af enkeltstående tilbud af forebyggende og afklarende karakter (som f. eks fysisk træning, kostvejledning, psykologhjælp, mestring af smerter og kroniske lidelser, kan fremme arbejdsfastholdelse og hurtig tilbagevenden). - At give viden om hvilken indsats, der virker." (Projektbeskrivelse. Aktive - hurtigere tilbage. Arbejdsmarkedsstyrelsen, 2008, s. 1).

Aktiveringsprojektet i Aalborg havde fire temaer, som de sygemeldte kunne melde sig til. Det var a) krop og sundhed, b) personlig udvikling, c) job, d) holdmøder og fællesarrangementer. Efter endt forsøgsperiode valgte Aalborg kommune at forsætte med projektet, dels fordi udgifterne til sygedagpenge faldt i forsøgsperioden, dels fordi mange af de sygemeldte borgere ikke var parate til at vende tilbage på arbejdsmarkedet. Den politiske holdning i Aalborg kommune var, at skulle de sygemeldte borgere have mulighed for at vende tilbage til arbejdsmarkedet, var der brug for en ekstra indsats

\section{Baggrund}

De sidste 30 års bestræbelser på at modernisere og omstille den offentlige sektor har medført en række nye reformer, strukturændringer, nye ledelsesformer og styringsredskaber, hvor sidstnævnte især konkretiseres ved standardiserede metoder, regelstyring og økonomistyring både i undervisningsregi, i beskæftigelsesregi og i socialt regi i kommunerne. Eksempelvis er krav om $\S 50$ undersøgelser på børn og ungeområdet, arbejdsevnemetoden og matchkategorise- 
ringen på beskæftigelsesområdet, funktionsevnemetoden på handicapområdet, metoder i socialt arbejde der følger standardiserede skemaer (Harder \& Nissen, 2008). Alt sammen har været et forsøg på at effektivisere og modernisere den offentlige sektor (Bømler, 2011). Det sidste nye er aktiveringspligten for sygedagpengemodtagere.

Moderniseringen af den offentlige sektor, ikke bare i Danmark men i hele Vesteuropa, er inspireret af New Public Management-konceptet. Et koncept der tager udgangspunkt i en kritik af den offentlige sektor som både for dyr og for bureaukratisk. New Public Management-konceptet er dog langt fra nogen ny opfindelse, idet der er tale om nogle klassiske liberale samfundsøkonomiske opfattelser af, hvad der skaber en omkostningseffektiv organisation. De centrale nøgleord i konceptet er udlicitering, privatisering, kontraktstyring, strategisk ledelse, indførelse af markedslignende forhold med frit forbrugsvalg og evaluering på baggrund af kvantitative data (Krister \& Ståhlberg, 1998). Indføring af markedslignende forhold og ønsker om frit forbrugsvalg skal bl.a. ses i lyset af en voldsom kritik af de professionelle socialarbejdere. Det var tidligere socialminister Ritt Bjerregaard, der var mest markant i sin kritik af de professionelle socialarbejdere. Hun beskyldte de professionelle socialarbejdere for at umyndiggøre klienter og for at fastholde dem i det sociale system. I en kronik i Information, der gengav Ritt Bjerregaards tale ved en OECD konference i 1980, gav hun udtryk for, at det var de professionelles betydning og råd, der skulle betvivles og hvor hun i øvrigt anså de professionelle som den største hindring for forsøg og fornyelse i den offentlige sektor (Bjerregaard, 1980). Senere blev kritikken fulgt op af den borgerlige regering. I Venstres reformprogram fra $1985 \mathrm{blev}$ det slået fast, at borgerne følte sig umyndiggjorte og var godt og grundigt trætte af at være omgivet af eksperter, der fortalte dem, hvordan de skulle gøre og i øvrigt skulle leve deres liv (Pedersen, 1986).

På trods af kritikken af de professionelle socialarbejdere og deres ansvar for at flere og flere borgerne blev fastholdt i det sociale system, fik vi i 1984 en ny pensionsreform, der gjorde det nemmere at blive bevilget førtidspension. Med den nye pensionsreform blev det muligt at blive bevilget førtidspension på baggrund af et kombineret socialt og helbredsmæssigt kriterium. Det kunne man ikke tidligere i henhold til lov om invalidepension og lov om enkepension. Den nye lov om social pension og de lempede tildelingskriterier fik den konsekvens at antallet af førtidspensionister steg voldsomt fra 1984 til 1990 (Frost, 2007). Det var en udvikling, der gav anledning til politisk bekymring både for samfundsøkonomien og for de sociale problemer, der kunne følge med den passive forsørgelse. Op igennem 
1990'erne oplever vi derfor, at der i stigende grad kommer fokus på aktivering frem for den passive forsørgelse. Vi begynder at bevæge os væk fra en welfare model til en workfare model. Hovedproblemet i velfærdsstaten er ikke længere et spørgsmål om de passive sociale ydelser og de sociale problemer, der følger i kølvandet. Nu er det et spørgsmål om de ledige, der er passive (Torfing, 2003). Derfor bliver der op igennem 1990'erne vedtaget en lang række reformer og stramninger i eksisterende regelsæt med det formål at bringe kontanthjælpsmodtagere, dagpengemodtagere og førtidspensionister ud på arbejdsmarkedet. Et af de første initiativer bag aktivlinjen var Socialministeriets projekt "Der er brug for alle". Projektet var målrettet førtidspensionister og kontanthjælpsmodtagere. Tankegangen bag projektet blev beskrevet således:

"Alle andre, dvs. de der kan yde noget skal have et tilbud, "de ikke kan sige nej til". Det skal forstås på den måde, at vi skal give folk et gennemarbejdet passende tilbud. Det skal være så godt og rigtigt til netop den, der skal bruge det, at de ikke kan sige nej, men hvis de alligevel siger nej, så må det få konsekvenser." (Socialministeriet, 1990, s. 9)

Fra begyndelsen af 1990'erne kommer der derfor i stigende grad politisk fokus på aktivering, der udmøntes i forskellige lovgivningsinitiativer. I 1991 bliver der indført en bestemmelse i den daværende bistandslov om ungdomsydelse, hvor hjælpen blev gjort betinget af, at de unge modtog et aktiveringstilbud. I 1993 bliver ungdomsydelsen udvidet til at omfatte alle kontanthjælpsmodtagere over 24 år. 'Fødslen' af aktivlinjen kan ses som et forsøg på at gøre op med "forsørgerkulturen" og genetablere velfærdsstatens moralske fundament (Carstens, 1998).

I 2008 bliver der indgået en trepartsaftale mellem arbejdsmarkedets parter og regeringen med det formål at nedbringe længerevarende sygefravær. Der skulle i højere grad være fokus på, hvilke indsatser, der var nødvendige for at nedbringe sygefraværet og øge muligheden for at vende tilbage til arbejdsmarkedet (Borg m.fl., 2008).

Indtil januar 2010 har de sygemeldte borgere hidtil været fritaget for aktivering. Med en ændring af sygedagpengeloven 1. januar 2010 blev det et krav, at de sygemeldte skulle aktiveres. Af sygedagpengelovens $\S 15$ fremgår det, at kommunen skal foretage en samlet vurdering af den sygemeldtes behov for en indsats $i$ henhold til lov om aktiv beskæftigelses indsats. I henhold til lov om aktiv beskæftigelses indsats $\S 27$ skal der udarbejdes en jobplan for den sygemeldte, hvor det skal fremgå, hvordan den sygemeldte kan vende tilbage til arbejdsmarkedet. Af $\S 28$ fremgår det, at jobplanen kan indeholde aktiviteter, der kan stabilisere og forbed- 
re en persons fysiske, psykiske og sociale tilstand. Siger de sygemeldte borgere nej til et aktiveringstilbud, kan kommunen stoppe udbetalingen af sygedagpengene.

To år før lovændringen udgav Beskæftigelsesministeriet en analyse af sygefraværet i 2008. Hovedbudskabet var, at de sygemeldte skulle tilbage til arbejdsmarkedet så hurtigt som muligt, og at det derfor var nødvendigt med en holdningsændring til hvordan vi bliver raske. Allerede i 2006 udtalte Claus Hjort Frederiksen til Berlingske Tidende at:

"Arbejde og sygdom er ikke modsætninger. Har man en dårlig ryg, er det dårligste man kan gøre, at ligge hjemme på sofaen. Det er meget bedre at holde sig i gang og genoptræne sine muskler. Det gælder også, hvis man lider af en depression. Så skal man ikke sidde alene hjemme i en toværelses lejlighed, men ud blandt kolleger." (Berlingske Tidende den 13. november, 2006)

På baggrund af den politisk udmeldte holdningsændring til, hvordan vi bliver raske, blev der gennemført et forsøgsprojekt i 16 jobcentre i 2009. Målgruppen for forsøgsprojektet var sygemeldte og fleksjob visiterede sygemeldte. Der deltog ca. 2500 personer i forsøgsprojektet. Formålet med forsøgsprojektet var at undersøge om sygemeldte, der gennemførte en aktiv indsats i sygedagpengeperioden, kunne opnå en større grad af selvforsørgelse eller fuld selvforsørgelse, end de ville have gjort uden en aktiv indsats. Rambøll-Management stod for evalueringen af forsøget. Hovedkonklusionen var, at indsatsen samlet set ikke bidrog til en øget grad af selvforsørgelse (Boll m.fl., 2010).

I Beskæftigelsesministeriets analyse af sygefraværet blev der henvist til national og international forskningsdokumentation for at for folk med ondt i ryggen, muskelproblemer og lignende lidelser var det sundt at holde sig fysisk i gang. Her skal det understreges, at der ikke findes videnskabelig dokumentation for, at det har en helbredende effekt at sende folk med alvorlige psykiske lidelser på arbejde eller i aktivering. Professor Tage Søndergaard Kristensen, der har forsket i arbejdsmiljø i over 30 år udtaler til Ugebladet A4 (2008:34):

"Det er helt forfærdeligt, hvad der sker, fordi folk ikke kan kende forskel på ondt i ryggen og en depression. Når vi taler om dem, der går psykisk ned på grund af noget, der er sket på deres job, så er noget af det værste man kan gøre, at sende dem tilbage på arbejde."

I en undersøgelse fra det Nationale Forskningscenter i Arbejdsmiljø fra 2010, konkluderes det, at der især mangler viden om tilbagevenden til arbejdsmarkedet for mennesker med mentale helbredsproblemer, og at de rapporter, der i øvrigt 
foreligger, ikke er udarbejdet med det formål at blive publiceret i videnskabelige sammenhænge. Konklusionen er, at der ikke er nogen videnskabelig evidens for effekten af indsatser, der har været målrettet sygemeldte med mentale helbredsproblemer (Borg m.fl., 2010). I en undersøgelse udført for arbejdsdirektoratet fra 2008 til 2009 var der fokus på borgere med diffuse lidelser (Christensen m.fl., 2009). Det vil sige lidelser, der er svære at udrede, og hvor der ikke er nogen anerkendt lægevidenskabelig diagnose. Det drejer sig bl.a. om kronisk træthed, problemer med bevægeapparatet og depression. For disse borgere er det blevet sværere at blive tilkendt en førtidspension, fordi det i lovgivningens forstand ikke kan "bevises" at en borger med en diffus lidelse er syg. Derfor er løsningen på problemet aktivering fremfor førtidspension (ibid.)

Etableringen af aktivlinjen på sygedagpengeområdet, og dermed holdningsændringen til hvordan vi bliver raske, kommer til udtryk gennem den lovgivningsmæssige ramme, hvor syg er lig med uarbejdsdygtighed på grund af sygdom (ibid.). Jobcentrene har derfor et stærkt fokus på diagnoser, fordi det er diagnosen, der i lovgivningens forstand "beviser", om en person er syg. Aktiveringskravet af de sygemeldte har indsnævret sygdomsbegrebet, idet det kun i ringe grad er muligt at vurdere det hele menneske og medtage de psykosociale forhold, der kan give funktionsproblemer for den sygemeldte (ibid.). Siden aktiveringspligten af de sygemeldte borgere blev indført har der været en løbende debat i medierne om, hvorvidt det var rimeligt at aktivere syge borgere. I medierne har der været flere eksempler på at alvorligt syge er blevet mødt med et krav om aktivering. Kritikken har ført til, at regeringen, Dansk Folkeparti, det Radikale Venstre og Liberal Alliance, har vedtaget et nyt regelsæt, der fritager alvorligt syge fra aktivering. Regelsættet trådte i kraft den 1. maj 2011 (Beskæftigelsesministeriet, 2011). Der er udarbejdet en såkaldt diagnoseliste, der omfatter alvorlige og livstruende sygdomme, eksempelvis kræft, blodprop i hjertet eller hjernen, svære psykoser, og komplicerede ulykkestilfælde, der kræver genoptræning.

Sideløbende med etableringen af aktivlinjen har staten i stigende grad indført sagsbehandlingsregler, der fungerer som et økonomisk styringsredskab af kommunerne, forstået sådan, at hvis reglerne om aktivering, rettidighed og opfølgning i sygedagpengeloven, aktivloven m.v. ikke er fulgt, så mister kommunen statsrefusion. Formålet med reglerne er at få kommunerne til at prioritere aktiveringen frem for den passive forsørgelse. Er borgerne ikke aktiverede får kommunerne 35 \% i statsrefusion. Er borgerne aktiverede får kommunerne 65 \% i statsrefusion. Fra 1. januar 2011 blev statsrefusionen sat ned til $30 \%$ for de passive sager og $50 \%$ for de aktive sager (Finanslovsaftale, 2011). 


\section{Metode}

Artiklen er i overvejende grad empirisk funderet og er udarbejdet på baggrund af et fokusgruppe- interview med tre sagsbehandlere og to projektmedarbejdere på et jobcenter i Aalborg kommune, der arbejder med aktivering af sygedagpengemodtagere. Rådgiverne og projektmedarbejderne er alle uddannede socialrådgivere. Der er tale om et pilotprojekt der skal danne baggrund for et større kvalitativt forskningsprojekt om udviklingen på sygedagpengeområdet og de faglige udfordringer, som medarbejderne står overfor. Kriteriet for udvælgelse af interviewpersoner var at de skulle være rådgivere og projektmedarbejdere der deltog i forsøgs- og udviklingsprojektet, og som efter lovændringen forsat arbejder med aktivering af sygedagpenge-modtagere. Formålet var at interviewe de rådgivere og projektmedarbejdere der havde længst erfaring med aktivering af sygedagpengemodtagere i Aalborg kommune. Det er områdelederen på jobcentret der har udvalgt interviewpersonerne. De centrale spørgsmål i fokusgruppeinterviewet var, hvordan sagsbehandlerne og projektmedarbejderne håndterer de faglige og etiske dilemmaer, som de oplever som en konsekvens af stramningerne i sygedagpengeloven. Den kvalitative tilgang er netop velegnet til at generere data om enkeltindividers oplevelser og erfaring. Tilgangen i fokusgruppeinterviewet er eksplorativt, idet udgangspunktet for fokusgruppeinterviewet har været at lade interviewpersonerne indkredse de problemstillinger og dilemmaer, som de finder centrale i forbindelse med aktiveringen af sygedagpengemodtagerne med henblik på at vurdere, om det er hensigtsmæssigt at gennemføre en større undersøgelse (Bitsch \& Pedersen, 2004). Der anvendes i vidt omfang citater, der beskriver interviewpersonernes holdning og oplevelser af problemerne. Interviewet er optaget på bånd og efterfølgende transkriberet. Fremstillingen af de oplevede problemer og dilemmaer er inddelt i fem overordnede temaer, der har været gennemgående i fokusgruppeinterviewet. De fem temaer er:

- Berøringsangst og den faglige udfordring

- Mødet med de sygemeldte borgere

- Omsorg og anerkendelse

- Standardisering, regelstyring og helhedssyn

- Bekymringer for de nye stramninger og den virksomhedsrettede aktivisering

Artiklens problemstilling er som nævnt begrundet $\mathrm{i}$ at vi mangler konkret viden om, hvordan de udførende led i jobcenterregi håndterer holdningsændringen 
til hvordan sygdom skal håndteres. I nærværende sammenhæng er de udførende led sagsbehandlere og projektmedarbejdere, der har den direkte borgerkontakt. Artiklen har inden offentliggørelse været til gennemlæsning af de rådgivere og projektmedarbejdere, der stillede op til fokusgruppeinterviewet. Selvom interviewets forskningsmæssige udgangspunkt var at indkredse og beskrive de faglige og etiske problemstillinger der kunne være forbundet med aktivering af sygemeldte borgere, så var det ikke de faglige og etiske problemstillinger, der fyldte mest hos interviewpersonerne. Det var derimod den New Public Management-inspirerede omstilling af den offentlige sektor, som oplevedes at være direkte kontraindicerende for menneskebehandlende organisationer, idet den indebærer standardiserede opgaveløsninger, der både er styret af rationelle kvantificerbare mål og styring af kommunernes adfærd gennem statsrefusionen. Artiklen afrundes derfor med nogle korte analytiske refleksioner over, hvordan den New Public Management-inspirerede omstilling og udviklingen på aktiveringsområdet generelt har bevæget sig væk fra en kommunikativ handlingslogik mod en instrumentel handlingslogik i den offentlige sektor. Det skal understreges, at anvendelsen af begreberne instrumentel- og kommunikativ handlingslogik ikke tager udgangspunkt i Habermas' forståelse af begreberne. Den instrumentelle handlingslogik tager udgangspunkt i New Public Management-konceptets forestilling om, hvad der skaber en omkostningseffektiv organisation. Den kommunikative handlingslogik tager udgangspunkt $\mathrm{i}$ det sociale arbejdes metoder, der er baseret på professionens etik og klientens samlede sociale situation. En handlingslogik, der ikke er domineret af en teknisk og økonomisk rationalitet, der kan måles kvantitativt (Krogstrup, 2002, Bømler, 2011). Det er en gennemgående problemstilling i fokusgruppeinterviewet er at rådgivere og projektmedarbejdere oplever at den instrumentelle handlingslogik i New Public Management konceptet med krav om standardisering, dokumentation, kontrol og økonomistyring går forud for helhedssyn i socialt arbejde og for socialfaglige vurderinger af borgerne. Det skal understreges, at der afslutningsvis kun er tale om ansatser til en analyse, da artiklen er baseret på et pilotprojekt med begrænset empiri.

Artiklen er delvist blevet til ved midler fra Undervisningsministeriets globaliseringspulje i form af tilførte timer og undertegnedes egen forskningstid på universitetet. ${ }^{1}$ 


\section{Berøringsangsten og den faglige udfordring}

Kravet om aktivering af de sygemeldte gav anledning til mange forskellige overvejelser blandt rådgivere og projektmedarbejdere i jobcentret. Konkret arbejder rådgiverne med myndighedsdelen i aktiveringen, mens projektmedarbejderne arbejder med aktivering indenfor de fire nævnte temaer. Der har både været modstand mod reglerne og overvejelser om, hvorvidt de gamle regler var gode nok. Hvad sker der f. eks hvis vi svigter de langvarigt sygemeldte? Fælles for rådgiverne og projektmedarbejderne er, at der er blevet reflekteret meget over lovgivningen og hvordan man på en metodisk og faglig forsvarlig måde kunne behandle sygemeldte borgere. Der har både været ambivalens i forhold til lovgivningen, men der har også været en faglig udfordring i at tænke over: Hvordan møder jeg min sygemeldte kollega eller borgeren med en brækket arm, der har sit arbejde at vende tilbage til. Hvorfor skal han aktiveres 10 timer om ugen? Eller hvad nu hvis det er en sygemeldt borger, der er alvorligt kræftsyg, der bliver bedt om at møde ind på jobcentret? I starten var aktiveringen af de sygemeldte på flere måder grænseoverskridende. En rådgiver og en projektmedarbejder havde bl.a. følgende overvejelser."I begyndelsen var det enormt grænseoverskridende, følte vi, da vi skulle til at begynde at indkalde sygemeldte borgere til aktive forløb. Det var jo virkelig nytænkning på området, men vi havde jo selv valgt at ville arbejde med det, så vi gik ombord i det og oplevede i begyndelsen, at det var svært at fä det sagt, fordi vi forventede, at der ville komme en stærk reaktion fra borgerne." (Rådgiver)

Projektmedarbejderen havde især overvejelser om, hvorvidt det var etisk i orden at kontakte sygemeldte borgere ud fra den betragtning, at de skulle have ret til at være syge og være i fred: "Jeg har været meget $i$ tvivl. Da jeg søgte herned havde jeg mange overvejelser om jeg i det hele taget kunne finde ud af det. Jeg havde det også sådan da jeg blev ansat, at det var en prøve. Det lød spændende ud fra det jeg fik at vide, men jeg var stadigvak $i$ tvivl om det var etisk $i$ orden og også med, hvordan jeg selv havde det med det. Og det der med at når man er syg og ikke kan få lov til at være syg. Jeg synes der er mange ting, som man hele tiden skal tage stilling til." (Projektmedarbejder)

Selvom det er reglerne, der i vidt omfang definerer indsatsen og hvor der konstant stilles krav om rettidighed og opfølgning, er rådgiverne og projektmedarbejderne meget opmærksomme på, at det arbejde de udfører, har betydning for, hvad kommunen kan hente hjem i statsrefusion. Fællesnævneren for både rådgivere og projektmedarbejdere er at møde borgerne med anerkendelse. En projektmedarbejder og rådgiver beskriver det således: "Vi har gjort os rigtig mange overvejelser om, hvordan vi møder borgeren første gang. Vi accepterer at der er nogle, der synes, det er træls 
at skulle møde op her. Vi kan ikke ændre på det, men vi er lydhøre overfor, hvad de siger og går ikke ind og prøver på at ændre deres holdning. Det er okay at de har det sådan og så må vi i frllesskab finde de muligheder, der passer bedst." (Rådgiver)

\section{Mødet med de sygemeldte borgere}

Det har været overraskende for både rådgivere og projektmedarbejdere, at det er et fåtal af sygemeldte borgere, der har reageret negativt på aktiveringskravet. Sagsbehandlerne og projektmedarbejderne havde en forventning om, at der ville komme nogle meget stærke reaktioner fra borgerne i retning af "at det vil vi ikke finde os i. Det kan i ikke tillade jer." At modstanden ikke var så stor som forventet, forklarer rådgiverne og projektmedarbejdere med, at de havde opdaget en forsømt gruppe i systemet. Det var langtidssygemeldte borgere med diffuse lidelser. Det kan i sig selv være vanskeligt at være sygemeldt, hvis man ikke har en lægeanerkendt diagnose. Borgerne føler sig mistænkeliggjort, fordi de møder systemer, der ikke anerkender dem og som ikke tror på dem. Over halvdelen af de borgere som rådgiverne og projektmedarbejderne møder er borgere med stress og depressioner. Det er borgere, der har svært ved at håndtere egen situation. "Mere end halvdelen af dem, der er her er sygemeldte med stress og depressioner og vi oplever mange, der kommer fra ledighedssystemet, som på en eller anden måde er blevet helt paralyseret $i$ det her showgame, hvor man skal søge så og så mange jobs og der egentlig ikke er nogen jobs at få. Så søger jeg bare nogle jobs og deltager i nogle ligegyldige computerkurser. Der er mange, der bliver trukket rundt $i$ systemet. De har ikke kraften og saften til at handle og finde ud af, hoad er der så af muligheder for mig. Det er slående, hoor mange der er ledige og som bliver trukket rundt i manegen til noget, som ikke giver mening." (Rådgiver)

Der er også borgere, der har reageret negativt, fordi de har følt at kravet om aktivering har været et indgreb i deres personlige integritet. Finanskrisen og de dårlige tider for erhvervslivet har været en medvirkende årsag til, at jobcentret møder sygemeldte borgere, der ikke tidligere har haft kontakt med et offentligt system og som møder systemet med fordomme."Jamen jeg er jo arkitekt. Jamen det er du jo. Lige pt. har vi rigtig mange advokater og arkitekter, der er her på grund af stress. Der er rigtig mange advokatkontorer og arkitektkontorer, der sætter deres medarbejdere på en sygemeldingskonto og mange af dem har altså en ide om, at det må være nogle sølle skvat, der kommer her." (Projektmedarbejder)

Selvom det ikke er alle der "tør op" undervejs i forløbet, så er der også nogle succeshistorier, der bekræfter rådgiverne og projektmedarbejdere $i$, at det nytter noget at tro på, at det arbejde de udfører, gør en forskel. "Jeg har en advokat, der altid 
har færdedes $i$ de finere kredse i Hellerup. Hun gik sygemeldt $i$ godt et år og hun har sagt til mig, at det fede ved det her er, at hun fik paraderne ned. Vores arbejde, det er at fa folk til at anerkende sig selv." (Projektmedarbejder)

Der findes også borgere, der mere eller mindre har resigneret. Det er borgere, der har dårlige erfaringer med de offentlige systemer og som har været i systemet længe. "Jeg oplever mange, der kommer og siger til mig. Hvad vil I med mig? Det er et udtryk for, at borgeren har trukket sig tilbage." Jeg overgiver mig for jeg magter ikke at gøre noget ved det her elendige system. Så I må gøre med mig næsten som I vil."

En helt anden udfordring er de sygemeldte borgere, der er gift og som er medlem af en a-kasse. De kan ifølge rådgiverne og projektmedarbejderne være svære at flytte, fordi de ved, at hvis de raskmelder sig og ikke har noget job, så er der udsigt til ingenting. De kan ikke få kontanthjælp på grund af deres ægteskabelige status og mister derved deres forsørgelsesgrundlag. Det er borgere, der falder ned mellem to stole i systemet og hvor motivationen for at raskmelde sig er lig nul.

\section{Omsorg og anerkendelse}

I håndteringen af faglige og etiske dilemmaer har nøglebegreberne været omsorg og anerkendelse. Det er rigtig mange sygemeldte borgere, der har dårlige erfaringer med offentlige systemer. Først og fremmest fordi de ikke bliver mødt med anerkendelse. For de enkelte borgere kan det være svært at overskue systemerne. Der er jobcentret, der er sygehuset, ventelister, a-kassen og egen læge m.v. Her er det at rådgiverne og projektarbejderne kommer ind med omsorg. "Her går vi jo ind og prover at drage omsorg for dem. Hvor ligger udfordringerne henne og prover at hixlpe dem med at få et overblik, fordi det jo er tit sådan, at når folk er sovset ind i det, så kører det hele rundt og de kan ikke forholde sig til det. Man prøver på at hjælpe dem med at dele det hele op. Hvor ligger udfordringerne henne og hvad er det egentlig vi kan hjælpe med? Netop sådan en simpel ting som at skulle til lægen, så sørger vi for, at folk har forberedt sig. Vi har rigtig gode erfaringer med at folk har en kalender eller en dagbog, hvor de skriver ned om gode dage og dårlige dage og hvor vi prøver at forberede os sammen. Når du skal ind til lægen. Hvad er så vigtigt for dig at få snakket om? Har du en derhjemme du kan snakke med om det." (Projektmedarbejder)

Omsorg og anerkendelse handler også om at kunne være uformel og at man kan tale sammen på, hvad rådgiverne kalder "et helt nede på gulvet plan". Her er erfaringen at det uformelle kan være med til at gøre borgerne hurtigere raske. Samtidig påpeger rådgiverne at bureaukratiet og de mange skemaer, der skal udfyldes komplicerer det uformelle og tager tiden fra den direkte borgerkontakt. 
Hjælp til at overskue er også at klæde borgeren på fremadrettet, så de har en plan med fremtiden på arbejdsmarkedet, når de bliver raskmeldte. Her er det vigtig at borgerne ikke bare overgår til ledighedssystemet uden at der er lagt en realistisk plan for det videre forløb. Handler det om uddannelse, omskoling, fleksjob m.v.? Omsorg og anerkendelse indeholder også motivationsarbejde. Der er mange borgere, der skal motiveres til at gå i nødvendig behandling, fordi de har så alvorlige psykiske lidelser, at professionel hjælp er en forudsætning for at borgerne kommer videre. Det er problemstillinger som projekt "Aktiv - hurtigere tilbage" ikke selv kan løse. "Nogen har rigtig mange lag af psykiske problemer og vi ved at nogen har varet udsat for vold og mobning på arbejdspladsen. Det er problemstillinger, der fylder meget og som de bliver ved med at vende tilbage til. Skal de vare sygemeldte på grund og stress og depression, er de altså nødt til at få gjort noget ved det. Her prøver vi at snakke med dem og motivere dem. Det kan godt være meget stor modstand, fordi det kan vare svært at skal ind og se på nogen ting i sig selv." (Projektmedarbejder).

\section{Standardisering, regelstyring og helhedssyn}

Både rådgivere og projektmedarbejdere giver udtryk for at regelstyringen påvirker kvaliteten af det sociale arbejde i negativ retning. Udover den næsten konstante strøm af nye regler og lovændringer, oplever rådgiverne og projektmedarbejderne i høj grad at medierne optræder som modspillere. Det rammer borgerne og det går ud over arbejdsglæden og fører i sidste ende til flere regler og mere bureaukrati. Den generelle opfattelse er, at medierne ikke synes at det er interessant og berette om de ting, der lykkedes. Der fokuseres udelukkende på de negative ting. "Det jeg kan blive rigtig ked af ved mit arbejde, det er at der er så meget negativ omtale. Jeg synes faktisk at jeg repræsenterer et godt stykke arbejde, men uanset, hvad de siger, så synes jeg det nytter noget, det jeg laver." (Projektmedarbejder).

Der er ifølge rådgivere og projektmedarbejdere en stærk tendens til, at politikerne lader sig styre af pressen og lovgiver ud fra de eksempler, medierne tager op. Det undersøges ikke, hvad der fungerer og ikke fungerer. "Det er jo også lidt sådan at regeringen regerer efter, hvad vej vinden blaser, hvis der er nogen der kommer og klager over nogle "pipkurser", så tager pressen det ud af en større sammenhæing og lave nogle generaliseringer og så tager politikerne en beslutning på baggrund af det og det er da amatøragtigt. Hvis man skal gøre det her professionelt, så må man gå i dybden og finde ud af, hvor problemet ligger. Hvad er det for noget vi skal gå ind og have fokus på?" (Projektmedarbejder) 
Mistænkeliggørelsen af de professionelle socialarbejderes rolle har sat grænser for metodefriheden i det sociale arbejde og det giver bekymring i forhold til fremtidens socialarbejdere "Jeg kan godt være bekymret for fremtiden. Jeg tænker jo, at da jeg startede for 20 år siden, havde vi nogle helt andre arbejdsvilkår og hvor vi også havde nogle helt andre muligheder for at finde vores egne ben, hvor vi kunne arbejde med helhedssyn og gøre alle de ting, som vi syntes var fagligt forsvarligt. De nye socialrådgivere, der kommer ud, fär jo ikke den mulighed, fordi det hele tiden handler om, at der skal krydses af - så er revisionen da tilfreds. Den gang var vi ikke underlagt de der ting." (Projektmedarbejder)

Metoderne i socialt arbejde er i udpræget grad blevet standardiseret. Det betyder konkret at helhedssynet og socialfaglige vurderinger er blevet skemalagte. Den socialfaglige udfordring er i høj grad, hvordan man producerer godt socialt arbejde i et felt, hvor man konstant bliver mødt med modsatrettede interesser og krav. Det organisatoriske skisma er at på den ene side så er der nogle regler og standarder, der skal følges og på den anden side skal rådgiverne og projektmedarbejderne sørge for at borgerne bliver mødt med anerkendelse og inddraget $\mathrm{i}$ beslutningsprocesserne. "På en eller anden måde kan det være svært at undgå at tænke $i$ kasser og økonomi, fordi systemet er skruet sammen som det er. Udfordringen for mig ligger $i$, at kassetænkningen ikke må fylde for meget i forhold til de overordnede mål, hvor mange måske vxlger at give køb på den del. Der er jo ikke noget nyt $i$ at tryk avler modtryk. Jo mere firkantede vi er overfor vores borgere, jamen jo hurtigere kommer borgerne til at bruge alt deres krudt på at yde modstand $i$ stedet for at arbejde med systemet og dermed arbejde hen imod en raskmelding. Det er jo også det, der bliver opfattet negativt i medierne og det fordrer jo ingenting." (Projektmedarbejder)

For rådgiverne og projektmedarbejderne er det en udfordring at tænke i muligheder frem for i begrænsninger sammen med borgerne. Her beskriver rådgiverne og projektmedarbejderne deres rolle som en buffer mellem system og borgere. En vigtig forudsætning for at håndtere modsatrettede krav og interesser er ifølge rådgivere og projektmedarbejdere, at organiseringen af "Projekt aktiv hurtigere tilbage" har en organisk organisering. Den organiske organisering er bl.a. karateriseret ved mindre specialisering og mere kommunikation såvel horisontalt som vertikalt og hvor medarbejderne har et bredt engagement i de opgaver, som de skal løse (Burns \& Stalker, 1961). ${ }^{2}$ Rådgivere og projektmedarbejdere er placeret i samme hus. Det giver bedre muligheder for samarbejde og for at finde løsninger på de forskellige problemstillinger. For borgere er det også en fordel at de har let adgang til både rådgiver og projektmedarbejder. Det er også rådgivernes og projektmedarbejdernes oplevelse, at ledelsen har givet mere plads til at arbejde 
helhedsorienteret ved at mindske sagsantallet og ved at lytte til rådgivernes og projektmedarbejdernes socialfaglige vurderinger af borgerne.

\section{Bekymringer for de nye stramninger og den virksomhedsrettede aktivering}

Fra den 1. januar 2011 er statsrefusionen som før nævnt igen blevet sat ned på sygedagpengeområdet og øvrige sociale ydelser. For sygemeldte der ikke er i aktivering modtager kommunerne nu 30 \% procent i statsrefusion og for de sygemeldte, der er i aktivering modtager kommuner $50 \%$. Af finanslovsaftalen for 2011 fremgår det, at det fremover skal være slut med at sende ledige og sygedagpengemodtagere ud på kurser, der ikke har et tilstrækkeligt jobsigte. Fremover skal aktiveringen være virksomhedsrettet. De fire temaer i projekt "Aktiv - hurtigere tilbage", som Arbejdsmarkedsstyrelsen argumenterede kunne være en hjælp til at få de sygemeldte tilbage til arbejdsmarkedet, er ikke længere en mulighed for kommunerne, hvis de vil bevare den høje statsrefusion. I Aalborg kommune har man politisk besluttet at køre projektet "Projekt aktiv og hurtigere tilbage" videre uanset den nedsatte statsrefusion. For det første fordi udgifterne til sygedagpenge er faldet i den periode, hvor projektet har kørt. For det andet er de svageste sygedagpengemodtagere ikke klar til en virksomhedsrettet aktivering, vurderes det af både rådgivere og projektmedarbejdere. Konsekvenserne ved at sende de sygemeldte ud på virksomheder, kan resultere i yderligere sygemelding. En rådgiver beskriver problemstillingen således: "Prøv også at tænke på den mængde af sygemeldte, der kommer her hos os og hvor nogen af dem er så dårlige og hoor der ikke er noget, der fungerer overhovedet. Hvis man så vælger at sige, at nu lukker vi "aktiv og hurtigere tilbage". Ja så er der nogen, der ville kortslutte. De er slet ikke der. De ville blive sendt hjem og konsekvensen af det, vil vare, at vi producerer langvarigt sygemeldte. På den måde kan man jo bare ikke sige, at fordi du er syg eller ledig, så er det bare med at komme ud at arbejde. Det er løsningen.(Projektmedarbejder)".

Rådgivere og projektmedarbejdere understreger at nedsættelsen af statsrefusionen ikke skaber flere jobs og heller ikke en større social ansvarlighed blandt virksomhederne. Kravet om virksomhedsrettet aktivering kan derudover give en "jobkonsulent-kø" hos virksomhederne. Risikoen kan være at virksomhederne bliver trætte af jobcentrenes pågåenhed. En helt anden bivirkning af de nye refusionsregler kan i følge rådgivere og projektmedarbejdere være, at man bliver fyret fra sit job og den næste dag kan man ansættes med løntilskud. I følge rådgivere og 
projektmedarbejdere er politikerne for dårlige til at vurdere, hvad der virker og ikke virker. Tendensen på aktiveringsområdet er stort set altid et "enten-eller" og ikke et "både-og". "Jeg syntes ikke at det er et enten eller, men et både og. Jeg synes det er synd, at det nu kun skal være målrettet virksomhedsaktivering og så skal vi nedlægge alt det andet, der fungerer for de svageste sygemeldte. Noget af alt det andet, er jo det, der skal til for at folk kan komme ud i en virksomhedsrettet aktivering. Så jeg synes det er synd, at man ikke kan sige " et både-og" i stedet for "enten-eller". Der er ikke nogen tvivl om, at det giver mening at sende folk ud på en rigtig arbejdsplads. Det tror jeg på, hvis folk kan det. Det jeg godt kan blive bekymret for er, at jeg har hørt et tal, der hedder 50 til 60.000 på årsbasis, som virksomhederne kan oprette med løntilskud." (Projektmedarbejder)

Løntilskuddet fremmer ifølge rådgivere og projektmedarbejdere heller ikke nødvendigvis virksomhedernes sociale ansvar, men løntilskuddet kan godt blive en økonomisk gevinst for virksomhederne. Hvis der vel at mærke drejer sig om en borger, der kan tilbyde en arbejdskraft. "Når løntilskuddet ophører og pengene slipper op, så kan de måske ikke bruge vedkommende, men har brug for at ansætte en ny med løntilskud." (Projektmedarbejder)

Generelt har både rådgivere og projektmedarbejdere blandede erfaringer med virksomhedernes sociale ansvar. Især fordi de kan konstatere at mange sygemeldte borgere bliver fyret, hvis de har været sygemeldte i mere end 3 måneder.

De nye refusionsregler og kravet om den virksomhedsrettede aktivering kan godt gå imod begreberne anerkendelse og omsorg, der har været nøglebegreber i Aalborg projektet. Selvom Aalborg kommune har besluttet at køre projektet videre, så er der ingen der ved, hvor længe beslutningen står ved magt. Generelt kan den virksomhedsrettede aktivering godt være til gavn for de borgere, der ikke har andre problemer end ledighed. Spørgsmålet er bare hvem der tabes. Den virksomhedsrettede aktivering giver ikke plads til differentiering og tager hånd om de borgere, der ikke magter egen situation og som ikke er et sted, hvor de ressourcemæssigt kan klare en virksomhedsrettet aktivering. Bekymringen hos rådgiverne og projektmedarbejderne er, om man på sigt risikerer at skabe flere syge borgere.

\section{Fra kommunikativ til instrumentel rationalitet - nogle analytiske refleksioner}

I 1970'erne var der en udpræget politisk tillid til, at der kunne opbygges et rationelt system, der var baseret på et bottom-up perspektiv, hvor de professionelle socialarbejdere kunne tilrettelægge indsatsen overfor socialt dårligt stillede. Pro- 
fessionaliseringen blev opfattet som en garanti for den enkeltes ret til en hjælp, der var uafhængig af personer og som hvilede på et professionelt skøn (Hulgård, 1997). Den tillid blev afløst af mistillid og kritik af de professionelle socialarbejdere i begyndelsen af 1980'erne. Med de løbske offentlige udgifter og et stigende antal bistandsklienter, kom der politisk fokus på de professionelles rolle. I Venstres reformprogram fra 1985 beskrives kritikken således:

"... det er mere og mere tydeligt at danskerne ikke er blevet lykkelige af at være omgivet af institutioner og professionelle behandlere fra vugge til grav. Mange foler sig umyndiggjort.

De er grundigt trætte af institutioner og eksperter, der sætter dem i gang, planlægger deres tilvarelse, opsøger og løser deres problemer, og fortzeller dem, hvordan de i det hele taget skal gøre." (Pedersen, 1986, s.11).

I bestræbelserne på at bremse væksten i den offentlige sektor og finde nye måder at løse de offentlige opgaver på, kom der for alvor fokus på brugerorienteringen. Brugerbegrebet afløste klientbegrebet. Tesen var at klienterne var blevet umyndiggjorte. $\mathrm{Nu}$ skulle klienterne ikke længere være klienter, men brugere, der i højere grad inddrages i sagsbehandlingen, have ansvar for eget liv og større valgfrihed (Bømler, 2011). Medens klientbegrebet i socialsektorregi ofte har en negativ signalværdi og som traditionelt set har betegnet de personer, der modtager sociale ydelser, så har brugerbegrebet derimod en positiv signalværdi. Brugerbegrebet signalerer at brugeren er aktiv og deltager både i planlægningen og $\mathrm{i}$ produktionen af offentlige ydelser. Det betyder ikke nødvendigvis at der er tale om ligeværdige relationer mellem brugeren og offentlige myndigheder, men der er imidlertid ikke nogen tvivl at brugerbegrebet har en langt større positiv signalværdi, end klientbegrebet har (Bømler, 2011). Ved at markedsgøre den offentlige sektor skulle brugerne i den udstrækning, det var muligt, have frit valg mellem offentlige institutioner (Klausen \& Ståhlberg, 1998). Brugerbegrebet er imidlertid ikke noget entydigt begreb. Er der tale om en bruger, der indgår i en afhængighedsrelation til en offentlig myndighed f.eks. sygedagpengemodtagere og kontanthjælpsmodtagere, er det ikke meningsfuldt at anvende begrebet. Her er der ikke tale om frit valg, idet der ikke eksisterer noget alternativ til den ydelse, som borgerne modtager. Det betyder at der både er tale om en afhængighedsrelation og en relation, der er påtvunget brugerne. I fokusgruppeinterviewet kommer det bl.a. til udtryk ved at sagsbehandlerne og projektmedarbejdere oplever at nogle borgere helt har resigneret og opgivet systemet. "Gør med mig, hvad I vil."

Den tyske sociolog S.O. Hirschmann definerer forholdet mellem bruger og offentlige myndigheder ud fra begreberne voice og exit (Hirschmann, 1970). Begre- 
bet exit er knyttet til brugernes frie valg, medens begrebet voice er et udtryk for de muligheder brugerne har for at ændre politikker og kutymer enten hos et privat firma, hvor de køber en vare eller hos en offentlig myndighed, hvor de modtager en ydelse. I den private sektor kan man som kunde frit vælge mellem forskellige leverandører og lever leverdøren ikke op til kundens kvalitetskrav vælges de fra. I forhold til sygedagpengemodtagere og det lovbestemte krav om aktivering, giver det ikke nogen mening at anvende begrebet exit, fordi der hverken er valgmuligheder eller alternativer til de ydelser som de modtagere.

Brugerorienteringen betød konkret at der blev iværksat en lang række centralt initierede metodeudviklingsprojekter sideløbende med at aktivlinjen blev skærpet. På den ene side kan de centralt fastlagte metodeudviklingsprojekter betragtes som en velmenende hjælpende hånd til at forbedre metoderne i det sociale arbejde. På den anden side kan det også opfattes som manglende accept af de professionelle socialarbejderes faglige kompetencer. Sagsbehandlere og projektmedarbejdere beskriver metodeudviklingen som en skemalægning af både helhedssyn og socialfaglige vurderinger.

Sideløbende med brugerorienteringen, metodeudviklingen og aktivlinjen blev der som før nævnt indført en ny type af sagsbehandlingsregler. Det er ikke sagsbehandlingsregler, der har nogen sammenhæng med sagsbehandlingsreglerne i retssikkerhedsloven. Det er sagsbehandlingsregler, der fungerer som et økonomisk styringsredskab. Det skal forstås sådan, at hvis kommunerne ikke følger reglerne om rettidighed, opfølgning og prioriterer aktiveringen frem for den passive forsørgelse, så mister kommunerne retten til statsrefusion eller også nedsættes den drastisk (Hjelmcrone \& Schultz, 2007). Her er der en markant risiko for at helhedssynet i socialt arbejde og socialfaglige vurderinger af, hvilke løsninger der er de bedst for borgerne tilsidesættes til fordel for, hvad der er bedst for kommunens økonomi. I fokusgruppeinterviewet kommer til det udtryk ved en bekymring for det sociale arbejdes fremtid og de vilkår som især de nyuddannede socialrådgiver kommer ud til i praksis.

Selvom der i udgangspunktet både for rådgivere og projektmedarbejdere var en berøringsangst $\mathrm{i}$ forhold til at møde de sygemeldte borgere med et krav om aktivering, så er det den New Public Management-orienterende omstilling, som rådgivere og projektmedarbejdere ser som den største barriere for at udføre fagligt kvalificeret socialt arbejde. Rådgivere og projektmedarbejdere oplever, at der konstant stilles spørgsmålstegn ved deres faglighed og dømmekraft. Generelt har mistænkeliggørelse af de professionelle socialarbejdere og andre der er beskæftiget i velfærdssamfundets menneskebehandlende organisationer, medført en ræk- 
ke af nye regler og standardiserede metoder i socialt arbejde. Stik imod det sociale arbejdes særlige karakter, der er baseret på en kommunikativ handlingslogik, hvor skøn og fleksibilitet, helhedsorientering og behovsorientering er centrale begreber, er den offentlige sektors opgaveløsningslogik blevet afløst af instrumentel handlingslogik (Krogstrup, 2002, Bømler, 2011). Den instrumentelle handlingslogik er analytisk begrundet $i$, hvad der skaber en omkostningseffektiv organisation. Set i et organisationsteoretisk perspektiv er vi tilbage ved de klassiske organisationsteoriers forestillinger om, hvad der skaber en omkostningseffektiv organisation (Bakka \& Fivelsdal, 2002). Da den amerikanske ingeniør Frederic W. Taylor i begyndelsen af 1900-tallet lancerede sine ideer om scientific management, var det bl.a. ud fra den tankegang, at gennemsnitsmennesket generelt nærede en stor uvilje mod at arbejde og derfor skulle det styres og dirigeres gennem frygten for straf. Ved at standardisere arbejdsprocesserne i industrien kunne man få et større afkast til virksomhedsejerne (Bømler \& Seemann, 2008). Selvom New Public Management konceptet har redet på en bølge af positive slagord, der har handlet om at skabe brugervenlige og fleksible offentlige organisationer, hvor medarbejderne tog ansvar for egen læring og udvikling (Åkerstrøm \& Born, 2001), så er der ikke nogen tvivl om, at det meget høje fokus på output kontrol med kommunerne, har mindsket brugernes indflydelse og de professionelle socialarbejdernes muligheder for at handle ud fra socialfaglige helhedsvurderinger, idet den høje statsrefusion kun kan hentes hjem, hvis der er fokus på aktivering. Her handler kvaliteten i opgaveløsningen primært om de professionelle socialarbejderes evne til at følge reglerne og de udstukne standarder. På et jobcenter i Århus kommune findes der (set i forfatterens optik) et skræmmende eksempel på, hvordan regeringens fokus på aktivlinjen, har fået markant indflydelse på den kommunale styring af medarbejdernes adfærd. I en sagsportefølge fra jobcentret, der blev offentliggjort den 3. juni 2010 i Socialrådgiveren fremgik det ved navns nævnelse, hvor meget de enkelte sagsbehandlere "skyldte" kommunen i statsrefusion. Sagsbehandlerne kan godt blive gode til at følge de udstukne standarder, men det løser ikke problemerne for de sygemeldte borgere med meget komplekse problemer. I relation til sygemeldte borgere med meget komplekse problemer ligger løsningen ikke lige for. I Aalborg projektet oplever rådgivere og projektmedarbejdere at de skal agere i organisatorisk felt, hvor de konstant bliver mødt med modsatrettede krav og interesser. Det er et dilemma som rådgivere og projektmedarbejdere forsøger at håndtere ved at fungere som en form for buffer mellem borgere og systemet. Hverken rådgivere eller projektmedarbejdere kan ændre på reglerne, men de kan 
forsøge at møde borgerne med anerkendelse, omsorg og hjælp til at overskue en ofte kaotisk situation.

På trods af næsten 3 årtiers politiske ambitioner med om at afbureaukratisere, regelforenkle og gøre den offentlige sektor mere brugervenlig og ikke mindst at inddrage borgerne i sagsbehandlingen, så kan rådgivernes og projektmedarbejdernes opfattelse af udviklingen bedst beskrives som en udvikling, der er gået stik imod hensigten. De vil gerne møde borgerne med anerkendelse og respekt, men generelt oplever de, at regelstyringen, økonomistyringen og standardiseringen, er med til at forringe arbejdsglæden i et arbejde, hvor de gerne vil gøre en forskel. Det er også rådgivernes og projektmedarbejdernes oplevelse, at medierne i høj grad er blevet en modspiller for muligheden for at udføre fagligt og kvalificeret socialt arbejde. Medierne fokuserer udelukkende på de negative ting og når de gør det, træder politikerne i karakter og ændrer på reglerne. Det giver kun anledning til mere bureaukrati og regelstyring. Det er også praktikernes oplevelse, at politikerne konstant har et behov for at træde i karakter, når der dukker "uheldige" eksempler på aktivering op i pressen. De nye stramninger på aktiveringsområdet, der trådte i kraft den 1. januar 2011 er det seneste eksempel på, hvordan negativ medie omtale af kommunernes aktiveringstilbud, har fået beskæftigelsesministeren til at stille krav om, at al aktivering skal være virksomhedsrettet. Det betyder at det fremover bliver meget vanskeligere end hidtil, at arbejde med differentierede løsninger for de sygemeldte borgere, der har andre problemer end ledighed. Derfor har Aalborg valgt at gå imod den centralpolitiske styring af kommunernes økonomi ved at fastholde Projekt "Aktiv og hurtigere tilbage". Det er ud fra den betragtning, at mange af de sygemeldte borgere ikke er klar til den virksomhedsrettede aktivering.

\section{Noter}

1: På Aalborg universitet blev diplomingeniøruddannelsen og socialrådgiverstudiet tildelt timer fra globaliseringspuljen. Globaliseringsmidlerne skulle anvendes til at styrke undervisernes inddragelse af praksis i undervisningen. Hovedkravet var at de studerende og praktikerne skulle inddrages i udviklingsprojektet. Den overordnede pædagogiske ramme på Aalborg Universitet var at underviserne skulle udvikle didaktiske tilgange til, hvordan samspillet mellem teori og praksis bedst kunne tilrettelægges. På socialrådgiverstudiet blev det konkret besluttet at globaliseringsmidlerne konkret skulle anvendes på praksisstudiet, der er placeret på henholdsvis 4 . og 5. semester. Kort beskrevet handler praksisstudiet om at kommunerne stiller de studerende en konsulentlignende opgave med en problemstilling, som de ønsker undersøgt med 
vejlederbistand fra universitet. Undertegnede var vejleder for en gruppe studerende (Mette Hou Gade, Lene Faurholt Jacobsen, Sarah Nedergaard Poulsen, Ulla Winther Simonsen, Tina Bøje Larsen) i efterårssemestret 2010. Jobcentret i Aalborg havde ønsket en undersøgelse af, hvordan sygedagpengemodtagere oplevede kravet om aktivering på trods af deres sygemelding. Parallelt til de studerendes undersøgelse skulle underviseren arbejde med en problemstilling indenfor samme område. Her var det oplagt at sætte fokus på rådgivernes og projektmedarbejdernes oplevelse af de dilemmaer, faglige og etiske problemstillinger, der kan være i aktiveringen af sygedagpengemodtagere.

2: Ved en undersøgelse i den engelske elektronik industri i 1960 identificerede Burns og Stalker et fundamentalt modstykke til den bureaukratiske organisationsform - den organiske organisationsform. Burns og Stalker konkluderede bl.a., at når det drejede sig om løsning af komplekse problemer, var den organiske organisationsform mere velegnet, idet løsningen af komplekse problemer kræver ekspertise og samarbejde på tværs i organisationen. Burns og Stalkers konklusioner har i høj grad vundet indpas i organisationsforskningen både i industrien og i den offentlige sektor. Især har organisationsforskere med empirisk forankring i socialsektorregi været optaget af Burns og Stalkers organiske organisationsform, idet den på mange punkter er mere velegnet til at løse behandlingsprægede opgaver.

\section{Referencer}

Arbejdsmarkedsstyrelsen (2008). Projektbeskrivelse. Aktive - hurtigere tilbage.

Bakka, J.F \& Fivelsdal, E. (red.) (2002). Organisationsteoriens klassikere. Handelshøjskolens Forlag. København.

Beskæftigelsesministeriet. (2008). Analyse af sygefraværet. København.

Beskæftigelsesministeriet. (2011). Nye regler fritager de mest syge for aktivering. København.

Boll, J. et al. (2010). Evaluering - Aktive - Hurtigere Tilbage. Rambøll Management. København.

Borg, V. et al. (2008). Danske TTA-indsatser for sygemeldte med mentale helbredsproblemer. Det nationale forskningscenter for arbejdsmiljø. København.

Burns, T \& Stalker, G.M. (1961). The management of innovation. Tavisstok. London

Bømler, T (1994). De normales samfund. Akademisk Forlag, København.

Bømler, T. (2010). Hvis arbejde er så sundt - så giv det til de syge. Socialpolitik - Tidsskrift for socialpolitisk forening, 2, 23-27.

Bømler, T. (red.) (2008). Sociale organisationer i en omstillingstid. Hans Reitzels Forlag. København.

Bømler, T. (2011). Fra Socialstat til Kontrolstat. Hans Reitzels Forlag. København.

Carstens, A. (1998). Aktivering - klientsamtaler og socialpolitik. Hans Reitzels Forlag. København.

Christensen, B.J. et al. (2009). Sygedagpengemodtagere med diffuse lidelser. Arbejdsdirektoratet. København.

Finanslovsaftale. (2010). Finansministeriet. København.

Finanslovsaftale. (2011). Finansministeriet. København. 
Frost, M. (2007). Førtidspension til unge. Samfundsøkonomen, 4, 18-23.

Hirschmann, S.O. (1970). Exit, voice and loyality. Harvard University Press. Cambridge.

Hjemcrone, N. \& Schultz, T. (2007). Den svages ret er den svage ret. Nyhedsbreve. Forlaget jurainformation, 9-11.

Hulgård, L. (1997). Værdiforandringer $i$ Velfærdsstaten. Forlaget Sociologi, København.

Klausen, K. \& Ståhlberg, K. (red.). (1998). New Public Management i Norden. Odense Universitets Forlag.

Klausen, J.(2002). Offentlig forsørgelse - en analyse af retssikkerheden mellem skøn, ret og pligt. Jurist og Økonomforbundets forlag, København.

Krogstrup, H.K. (2002). Når socialt arbejde bliver en standardvare. Nordisk Socialt arbejde, 22, $122-130$.

Olsen, P.B. \& Pedersen, K. (2004). Problemorienteret projektarbejde. Roskilde Universitets Forlag. København.

Pedersen, T. Ø. (1986). Innovation i kommunal Planlægning. Århus Universitet.

Rasmussen, A.F. (1993). Fra Socialstat til Minimalstat. Forlaget Samleren, København.

Socialministeriet. (1990). Der er brug for alle. København.

Torfing, J. Den stille revolution i velfærdsstaten. I Madsen P.K. \& Pedersen L.(red.). Drivkræfter bag arbejdsmarkedspolitikken. Socialforskningsinstituttet, København.

Åkerstrøm, N. \& Born, W.B. ( 2001). Kærlighed og omstilling. Italesættelsen af den offentligt ansatte. Nyt fra Samfundsvidenskaberne. København. 


\section{Abstracts in English}

\section{Musculoskeletal aging, work ability, and 'health resource/risk balance'}

\section{Anne Møller \& Susanne Rewentlow}

Physical activity in leisure-time is recommended by authorities as healthy while physical activity at work is often considered to be harmful to your health. In Denmark the term 'nedslidning' is used to describe the gradual physical deterioration due to exposures in the work environment. This article presents a review of the literature about physical work and health, and the historical and present use of the term 'nedslidning' is described. Instead of using the not vey specific term 'nedslidning', the article suggests that the process of deterioration is seen as part of the musculoskeletal ageing process. The reader is presented to a 'life course perspective' on the aging process and to a 'life course perspective' on the relationship between the physical activity in work life and the following physical function in midlife. The paper concludes with a recommendation of the use of these perspectives in future occupational research and in daily life, where professionals are working with the relationship between work environment and health. 


\section{Social pain in modern working life from the perspective of work psychology}

\section{Einar Baldvin Baldursson}

It is often argued, that modern work and living in globalized knowledge society involve new demands and social stressors. This paper argues that it is meaningful to assume the existence of a psychological immune system that has emerged through the evolution of social mammals and humans. Accord to the theory, this system is activated in the case of social threats, loss or damage. When activated it causes psychological pain and depressive reaction. Similar to the innate immune system, the psychological immune system involves (social) behavior with the goal to limit damage and improve the odds for recovery. In the paper it is argued that modern work involves increased focus on social relations and cooperation. The experience of permanent changes at work, increased pressure and emotional demands lead to increasing risk for social loss and defeat at work. According to this theory such experiences will lead to psychological pain and depressive mental states. This theory can contribute to explaining the increasing prevalence of stress and depression.

\section{Normative and methodological perspectives on "labour" as a concept within the discourse concerning the economy of health programs}

\section{Steen Brock \& Bo Allesøe Christensen}

This paper begins by recounting important phases in the development of the concept of labour. Then the Capability Approach to welfare economy, by Amartya Sen, is presented as is the direction of socio-psychology called Positioning Theory. Accordingly, the paper advocates a way in which to assess the economy of health programs as a cornerstone within Public Health Strategies to the effect that the concept of labour is important in this context. All way through, the paper examines the inescapable gap between a professionalized authoritative viewpoint on labour and an authentic perspective thereupon. 


\section{Stories of being unemployed and socially excluded}

Eva Ladekjær Larsen, Pernille Tanggaard Andersen E Carsten Kronborg Bak

We live in a modern society where working life both is a source to identity and wealth and at the same time occupy our time and energy. But how is it to be unemployed and excluded from this working community? And why is it so hard to reintegrate people at the labour market? Based on theory of social exclusion these questions are explored by analysing socially vulnerable citizens' everyday lives and the complex social problems that have been accumulated through out their lives. We demonstrate how these accumulated risk profiles create barriers to be included in working life and often involves a high degree of marginalisation.

\section{Does sickness absence necessitate certification by a medical physician?}

\section{Torunn S. Olsen E Nils Fleten}

Most Western countries require a medical certificate for payment of sickness benefits in prolonged absence spells. Based on an intervention enabling self-certified sick leave up to 365 days in the municipality of Mandal, this article discusses whether a medical certificate is necessary to legitimate sick leave. The municipality's absence registry and questionnaire data form the basis of this article. In Mandal self-certification has become the rule, both for short- and long-term sick leave. For short-term absence, the transition to self-certification has reduced absence length and return to work has become more evenly distributed throughout the week. For sick leave in excess of 16 days, absence length has increased, but not significantly. The proportion of graded long-term sick leave significantly increased in self-certified episodes, from 23 percent the first year to 43 percent the third year. A large and increasing majority of the employees are satisfied with extended self-certification. Those whom still prefer a doctor's sick note, are either critical to how they are followed-up at the workplace or feel that self-certification is a burden. The transition to self-certification as main documentation for sickness absence has not increased absence levels. During long-term absence spells employees consult their doctors. This indicates that the employees behave responsibly when they self-certify and retain contact with their doctor for medical purposes.The intervention suggests that mandatory certification by a doctor is not necessary for legitimising sick leave, even long-term absence. 


\section{Socialworkers in a field of tension between politics and the needs of their clients}

\section{Tina Bømler}

This article discusses the obligatory job activation measures directed toward workers receiving temporary sickness benefits, a policy that took effect on 1. January 2010. The requirement that workers on sick leave be subject to activation measures so they can return to work more quickly indicates a change in attitude about how we become well again. The purpose of this article is to describe and analyze how social workers in the Danish municipality of Aalborg work with activation of workers on sick leave. It describes how they manage the professional and ethical dilemmas they experience due to the specific activation requirements directed toward workers on sick leave. The problem takes its point of departure in our lack of specific knowledge about how the municipal job counselling centres manage the activation of those receiving sick leave benefits.

This article is a part of a pilot project, and therefore based on a limited amount of data. The pilot project should be seen as a preliminary phase of a larger qualitative study of the methodological challenges in the sick leave sector. The article is based on a focus group interview with five social workers in a job centre in the municipality of Aalborg. The results of the pilot study have been surprising. Even though there are professional and ethical dilemmas facing the social workers in the job centre, these are of less importance than the New Public Management based restructuring that has been taking place in the Danish public sector for nearly thirty years. Regulatory constraints, budget controls and standardization of the methods of social work are experienced by the social workers as the greatest obstacle to carry out professionally qualified social work. The requirements connected with regulations, standardized methods and budget controls have placed the social workers in a field of tension between politics and their clients' needs. Hence, the professional social sector workers find themselves compelled to manoeuvre in an organizational context that places contradictory demand on their activities. 


\section{Sickness absence - past and present. Work and sickness between rights and duties in the modern welfare state}

\section{Claus D. Hansen}

What can we learn about the relation between work and sickness by studying incapacity for work as it manifests itself in the way in which the phenomenon is discursively constructed and regulated by law in the period from 1950 to the present? This question is examined by tapping into various historical materials taken from newspapers, magazines, political debates and legislation. The material is analysed from a perspective inspired by Reinhart Koselleck that tries to infer the historical processes from the changes in which a concept is used differently over time. The analysis - drawing on Habermas and Foucault - reveals a fundamental ambivalence of sickness absence: on one hand, the regulation of temporary incapacity for work changed for the better by allowing workers to take sick leave when they felt like it without being economically punished. On the other hand, these newly won rights had unintended consequences e.g. leading to the exclusion of workers with fragile health status. At the same time, the use of statistics and sickness absence interviews can be seen as 'technologies of power' that normalize the way in which work and sickness can be integrated in our society. 


\section{Forfatterliste}

\section{Anne Møller}

Læge i blokstilling til almen praksis og ph.d-studerende ved Forskningsenheden for Almen Praksis København, Arbejdsmedicinsk Afdeling Køge Sygehus og Det Nationale Forskningscenter for Arbejdsmiljø. Hendes Ph.d.-projekts titel er: 'Arbejdets betydning for aldringsprocessen. Giver fysisk krævende arbejde tegn på tidlig aldring hos midaldrende danskere? og anvender data fra Copenhagen Aging and Midlife Biobank, som udgår fra København Universitet. Pt. arbejder Anne Møller som reservelæge i Psykiatrien Øst, Region Sjælland. Ph.d.-projektet ventes færdigt forår 2013.

\section{Susanne Reventlow}

Adjungeret professor ved Institut for Folkesundhedsvidenskab, praktiserende læge, Dr.Med.Sci. og forskningsleder ved Forskningsenheden for Almen Praksis i København. Er magister i antropologi fra Institut for antropologi, Københavns universitet. Hendes første forskning, i forbindelse med ansættelse på SFI (Social Forsknings instituttet i dag Det nationale forskningscenter for velfærd) som student og færdig læge, handlede om det langvarige sygefravær og nedslidning. Hun beskæftiger sig med almenmedicinsk forskning med interesse for teori og metodeudvikling inspireret fra antropologien. Hendes egen forskning har i en længere periode omhandlet risiko, medicinsk teknologi, kroppen, forebyggelse og kommunikation.

\section{Einar B. Baldursson}

Født i Reykjavik, 1953. Cand.psych fra Aarhus Universitet 1980. Arbejdet ved Aarhus og Aalborg Universitet, og de Arbejdsmedicinske Klinikker i Herning og Skive. Selvstændig konsulent i en årrække. Forfatter til bogen "Hyperstress" (Frydenlund 2009). Medstifter af "The European Academy of Occupational Health Psychology". Aktuelt lektor i klinisk socialpsykologi ved Stressklinikken Aalborg Universitet. 


\section{Steen Brock}

Lektor ved Institut for Kultur og Samfund, Aarhus Universitet. Dr. Phil. på en afhandling om Niels Bohrs fysikfilosofi og ph.d. på en afhandling om moderne moralfilosofi. Har publiceret mange artikler om videnskabsfilosofi og kulturfilosofi og redigeret flere bøger, senest Folkesundhed. Perspektiver på dansk samfundsmedicin.

\section{Bo Allesøe Christensen}

Cand. mag i religionsvidenskab og filosofi fra AU. Forsker p.t. i forholdet mellem de antropologiske elementer oplevelse/erfaring og økonomi. Er desuden redaktør ved forlaget Philosophia.

\section{Eva Ladekjær Larsen}

Antropolog, mag.art, ph.d. og ansat som forsker på Folkesundhed og Kvalitetsudvikling, Region Midt. Hendes forskningsinteresser er marginaliserede befolkningsgrupper og boligområder, forebyggelse af arbejdsmarkedseksklusion og social ulighed i sundhed.

\section{Pernille Tanggaard Andersen}

Sociolog, ph.d. og lektor på Forskningsenheden for Sundhedsfremme, Syddansk Universitet. Hendes forskningsinteresser er bl.a. social ulighed i sundhed, køn, klasse i forhold til livsstil og livsformer samt arbejdsmarkedet.

\section{Carsten Kronborg Bak}

Sociolog, ph.d. og adjunkt på Center for Landdistriktsforskning, Syddansk Universitet. Hans forskningsinteresser er social ulighed i sundhed, fattigdom, levekår og social eksklusion i socialt udsatte boligområder og udvikling af interventionsprogrammer i socialt udsatte boligområder.

\section{Torunn S. Olsen}

Arbeider som universitetslektor og forsker ved Institutt for arbeidsliv og innovasjon, Fakultet for økonomi og samfunnsvitenskap, Universitetet i Agder. Olsen har vært prosjektleder for en rekke evalueringer, blant annet evalueringen av Tillitsprosjektet $\mathrm{i}$ Mandal kommune. Forskningsinteressene er i hovedsak knyttet til hva som fremmer og hemmer nærvær i arbeidslivet.

\section{Nils Fleten}

Arbeider som førsteamanuensis ved Institutt for Samfunnsmedisin, Det helsevitenskaplige Fakultet, Universitetet i Tromsø. Han er spesialist i samfunnsmedisin og har bistilling som rådgivende overlege i NAV. Forskningsinteressene er i hovedsak sykefravær, både ut fra en epidemiologisk tilnærming og intervensjons tilnærming som forsøket med utvidet egenmelding i Kristiansand. 


\section{Tina Bømler}

Uddannet socialrådgiver og cand.scient.adm. og ph.d. Hun er lektor på Aalborg Universitet ved Institut for Sociologi, Socialt arbejde og Organisation. Forfatteren har skrevet en række bøger om bl.a. samfundets skyggesider.

\section{Claus D. Hansen}

Født 1976, uddannet sociolog fra Aalborg Universitet (2004), har efterfølgende taget sin ph.d.-grad sammesteds med en afhandling om sygefravær (En sociologisk fortælling om sygefravær, 2010). Siden august 2010 adjunkt på Institut for Sociologi og Socialt Arbejde, Aalborg Universitet. Var fra 2004-2010 ansat på Arbejdsmedicinsk Klinik, Regionshospitalet Herning, hvor han bl.a. arbejdede på sygefraværsprojektet ASUSI. Har i den forbindelse skrevet flere artikler om sygenærvær (at folk går på arbejde på trods af, at de føler sig syge). Siden 2007 tilknyttet ungdomskohorten VestLiv - Livskvalitet blandt unge fra Vestjylland som følger to årgange fra det tidligere Ringkøbing Amt med henblik på at afdække årsager til social ulighed i helbred. Underviser og vejleder på sociologistudiet fortrinsvis i kvantitative metoder. Hjemmeside: http://personprofil.aau.dk/ profil/103392 